\title{
The 1780s: Global Climate Anomalies, Floods, Droughts, and Famines
}

Vinita Damodaran, Rob Allan, A.E.J. Ogilvie, G.R. Demarée, Joelle Gergis, Takehiko Mikami, Alan Mikhail, Sharon E. Nicolson, Stefan Norrgård, James Hamilton ${ }^{1}$

\section{Introduction}

In 1793, William Roxburgh, surgeon of the English East India Company in Samuelcottah (Madras presidency, India), reported to the President's Council on the failure of the South Asian Monsoon between 1789 and 1792, arguing that its severity in South Asia had been approached only by the droughts of 1685-87. His meteorological observations and his collection of data on rainfall and cyclones were critical to the new science of climatology that was emerging in the colonies. Building on this archival evidence, and with corroborating evidence from St Helena, New South Wales, Mexico, and Montserrat, the environmental historian Richard Grove argued in Nature that the droughts of 1789-92 were part of an El Niño event with global ramifications. ${ }^{2}$ Grove contended that the associated famine in Madras presidency, which claimed in the region of 600,000 lives, was part of a global disaster, resulting from extreme climatic conditions associated with this particular period of intense El Niño expression. ${ }^{3}$

How global was the event that Grove describes? How can we better analyse the climate anomalies of this period? This paper draws on the contribution of Rob Allan and the regional expertise of Joelle Gergis (Australia), A.E.J. Ogilvie and G.R. Demarée (Iceland), Sharon Nicolson and Stefan Norrgård (Africa), Alan Mikhail (Egypt), Takehiko Mikami (Japan), as well as James Hamilton and lead author Vinita Damodaran (South Asia). It offers an up-to-date reconstruction of global-scale climate anomalies during the 1780s before moving on to discuss the social impacts of these climate anomalies in Iceland, Egypt, India, Australia, Africa, and Japan.

\section{Reconstructing Global Climate in the 1780 s}

The decade of the 1780s saw the first systematic instrumental observations of weather. By then, some of the earliest attempts to develop European instrumental meteorological networks had taken shape, including the Mannheim Societas Meteorologica Palatina (178192) (Germany), the Societé Royale de Médecine (France) (1776-89), the Baierische

\footnotetext{
${ }_{1}^{1}$ Affiliations-Vinita Damodaran (Historian, University of Sussex) Rob Allan (Climate scientist, U.K. Met office), A.E.J. Ogilvie (Climate Historian, Stefansson Arctic Institute and Institute of Arctic and Alpine Research), G.R. Demarée, (Meteorologist, Royal Meteorological Institute of Belgium), Joelle Gergis (Climatologist, University of Melbourne), Takehiko Mikami (Geographer, Teikyo University) Alan Mikhail (Historian, Yale University) Sharon E. Nicolson (Earth Scientist, University of Wisconsin-Madison) Stefan Norrgård's (Climate historian, Abo Akademi University) James Hamilton (Graduate researcher, University of Sussex)

${ }^{2}$ Roxburgh, W. MS Report to the President's Council 6 Feb, East India Company Boards Collections, ref.no. F/4/99 British Library India Office Collections, London cited in Grove, 1998, 318-9.

3 Grove, 1998, 318.
} 
Ephemeriden (Germany) (1781-89), and the Academia Medico-Matritense (Spain) (17801825) networks \{see chapter 2.3.4\}. ${ }^{4}$ Unfortunately, with the coming of the French Revolution and the Napoleonic Wars in the late $18^{\text {th }}$-early $19^{\text {th }}$ centuries, these networks collapsed, and it was colonial metereological networks that were to prove more robust, such as those initiated by William Roxburgh.

Early instrumental weather records during this decade can be found in the vicinity of Calcutta, India (1784-1785) and at Baghdad and Basrah in Iraq (1782-84). ${ }^{5}$ In India, what became the English East India Company's (EIC's) observatory at Madras-officially established in 1792- had evolved from the private observatory of William Petrie in the 1780s. ${ }^{6}$ In Australia, the establishment of the British colony of New South Wales in Australia in 1788 began the record of instrumental weather observations in that country. ${ }^{7}$ While in Mauritius, the Jean Nicolas Cere and Lislet Geoffery began the first systematic meteorological observations of the Indian Ocean region during the 1770s-1790s. ${ }^{8}$ In the marine sphere, scientific instruments such as thermometers and barometers were beginning to be regularly used on ships of all nations. Such records survive from the English East India Company ships trading with India and China from the 1780s, the First Fleet sailing from England to Australia with the first European colonists in 1788, and a number of major expeditions and circumnavigations, such as those of James Cook and JeanFrançois La Pérouse and George Vancouver. ${ }^{9}$

The international ACRE (Atmospheric Circulation Reconstructions over the Earth) Initiative has undertaken various efforts to recover, image/scan, and digitise such early instrumental, terrestrial, and marine observations, and these have been linked into the evolving WMO International Data Rescue (I-DARE) activities portal. ${ }^{10}$ Both historical documentary and paleo/proxy analyses still provide essential material and evidence with which to investigate the global to regional climatic regimes and patterns of the 1780s. The weather of the 1780s specifically over Europe has been reconstructed by John Kington of

\footnotetext{
${ }^{4}$ Alcoforado et al., 2012.

${ }^{5}$ Trail, 1799; Cotte, 1788. However, in some regions of the world which regularly experience active tectonic events, with earthquakes and volcanic eruptions, initial efforts to set up and/or maintain colonial observatories and their records around this time were dashed by the continual loss of instruments to breakages. The long distances and costs required to obtain new instruments, eventually thwarted many of these endeavours. This was particularly a problem in the East Indies (Zuidervaart and van Gent, 2004; Zuidervaart and van Gent, 2013). Johan Maurits Mohr's expensive and well-equipped personal observatory that he had built in 1765 near Batavia on Java, was damaged by an earthquake in 1780 and then fell into ruin and was demolished in 1812. At its peak, it had been visited by the likes of Bougainville and Cook on their expeditions.

${ }^{6}$ Ananthasubramanian, 1991.

7 Gergis et al., 2009.

8 Mulnier and Paya, 1974.

${ }^{9}$ Brohan et al., 2012; Gergis et al., 2010.

${ }^{10}$ International Data Rescue Portal. http://ooxo.nl/opdrachten/I-DARE/content/dare-success-stories. Accessed April 26, 2016.
} 
the Climatic Research Unit in the form of historical weather maps ${ }^{11}$ Based on this evidence, we can identify both major climatic episodes and the human consequences as discussed in the following sections.

<<Insert Figure 1 here >> <<Caption: Instrumental weather observations in the meteorological journal of William Dawes (14 September 1788 to 6 December 1791) at Sydney Cove, New South Wales. >>

\section{The Laki Fissure Eruption of 1783}

During the year 1783 much of the Northern Hemisphere was affected by a phenomenon that many contemporaries described as the "great dry fog." The origin of this fog was a major volcanic eruption in the county of Vestur-Skaftafellsýsla, in the southeast of Iceland. In the non-Icelandic literature, this eruption has often been referred to as the "Laki" eruption. Strictly speaking, this is a misnomer, since the eruption did not occur on Mount Laki, but on either side of it. In Icelandic it is often called Lakagígar, the "Laki fissure" eruption. The total length of the Lakagígar crater row from one end to the other is $27 \mathrm{~km}$, divided by Mount Laki into two nearly equal parts. The eruption is also referred to in Iceland as Skaftáreldar, or "Skaftá fires," from the nearby river Skaftá.

The first signs of the eruption were some weak tremors felt in May, and then strong earthquakes in southeast Iceland in early June. The eruption itself began on June 8. This year also brought a marine volcanic eruption, on a much smaller scale, off Reykjanes in the west, as well as volcanic activity in Vatnajökull. ${ }^{12}$ The effects of the eruption were felt and seen all over Iceland, mainly in association with the falls of tephra, and there are numerous contemporary descriptions. ${ }^{13}$ The eruption lasted until February 1784, with a lava flow covering an area of $580 \mathrm{~km}^{2}$, making it one of the most noteworthy and largest fissure eruptions in historical times.

The eruption had a catastrophic effect in Iceland, not because the eruption caused direct loss of life, but because of the indirect effects of volcanic gases and ashes distributed by wind. Poisonous substances in the volcanic dust adversely affected vegetation, killing numerous domestic animals, the backbone of the Icelandic economy. The grass, the basic sustenance of the grazing livestock, became fluorine poisoned, and within a year of the eruption $53 \%$ of the cattle, $80 \%$ of the sheep, and $77 \%$ of the horses died. ${ }^{14}$ The Lakagígar eruption must be seen as the primary cause of the ensuing famine, which came to be known in Icelandic as Móðuharðindin, "The Famine of the Mist," from the volcanic dust haze. ${ }^{15}$ It is

\footnotetext{
${ }^{11}$ Kington, 2009.

12 Thordarson and Self, 1993.

${ }^{13}$ Gunnlaugsson et al., 1984; Ogilvie, 1986; Demarée and Ogilvie, 2001.

14 Thórarinsson, 1969; Thórarinsson, 1979.

${ }^{15}$ Bjarnar, 1965.
} 
estimated that the total death toll of Móðuharðindin reached $19-22 \%$ of the Icelandic population, or approximately 10,000 people. ${ }^{16}$

The difficulties in Iceland set in motion by the Laki fissure eruption were further compounded by an epidemic of smallpox, and also the very severe weather that had already begun in $1782 .{ }^{17}$ Furthermore, the sea ice that drifts on the East Greenland Current to the shores of Iceland was extensive in 1781, 1782, 1783, and 1784, which significantly lowered temperatures on land. In the past, the presence of sea ice had many negative effects in Iceland, preventing access to fishing grounds and the arrival of trading vessels. ${ }^{18}$ In recent times, there has for the most part been little sea ice off Iceland's coasts.

The consequences of the Lakagígar eruption were not confined to Iceland. ${ }^{19}$ The fine ash and volcanic dust that rained down on most parts of Iceland were also reported in many regions of northern Europe. Examples come from the Faeroe Islands, Caithness in Scotland, Copenhagen, Friesland, Bergen (Norway), and northern Germany. The dry fog also appears to have been witnessed in areas as far apart as Labrador, Newfoundland, the Tunisian coast, Asia Minor, and possibly China. ${ }^{20}$ The dry fog of the year 1783 lasted for approximately three months, starting around mid-June, with most of the final descriptions dating from September 1783.

European historical sources noted many harmful effects of the dry fog on the environment. Specifically, these negative effects seem to have been limited mainly to the banks of the North Sea and Baltic Sea regions. However, other sources reported its beneficial influence on the vegetation and harvest. These include accounts from regions in Germany, Austria, Hungary, Livonia (comprising nearly all of modern-day Latvia and Estonia), and Upper-Hungary (modern Slovakia). ${ }^{21}$ Another factor to note was that the 1780s were one of the coldest decades in the Central England Temperature (CET) series. There was a notable sequence of three cold years, 1784-86, where the annual mean for each year was more than $1^{\circ}$ below the series average. ${ }^{22}$

Benjamin Franklin has been credited as the first to suggest a relationship between volcanic eruptions and climate. ${ }^{23}$ The evidence for this relationship is now unequivocal, but the discussion on its exact nature continues. ${ }^{24}$ For Europe at least, there is evidence that explosive eruptions tend to lead to cold summers and warm winters. A sulphate aerosol dry fog could also lead to a cold summer, but this would depend on the exact composition

\footnotetext{
16 Gunnlaugsson et al., 1984.

17 Ogilvie,1986.

18 Ogilvie, 2010.

19 Stothers, 1996; Demarée and Ogilvie, 2001.

20 Demarée et al., 1998; Demarée and Ogilvie, 2001.

21 Demarée and Ogilvie, 2001.

22 "British Weather from 1700 to 1849. Accessed April 26, 2016. http://www.pascalbonenfant.com/18c/weather.html.

23 Franklin, 1785.

${ }^{24}$ Gettelman et al., 2015; Santer et al., 2015.
} 
of the aerosol. In the case of the 1783 event, such debates regarding aerosol composition are relevant with regard to both the cold winter of 1783-84 and the hot summer of 1783 . Such questions regarding volcanic eruptions and climate remain highly relevant in the present context of global change and debates concerning the relative contributions of natural climate variability and greenhouse gas-induced warming. ${ }^{25}$

\section{Protracted Episodes: El Niño 1782-84 and La Niña 1785-90}

Aside from the effects of the Lakagígar eruption,1783 was an extraordinary year for several reasons, including the occurrence of extreme weather conditions, other volcanic eruptions, earthquakes, and epidemics in many parts of Europe and elsewhere. ${ }^{26}$ With regard to epidemics, the evidence suggests that the concentrations of noxious gases and the volcanic ash produced by Lakagígar were responsible for an increased mortality in England, France, Belgium, and the Netherlands. ${ }^{27}$

A 2011 study by Rosanne D'Arrigo and colleagues has suggested that the impacts attributed to the Lakagígar eruption may actually have resulted from the occurrence of a negative North Atlantic Oscillation (NAO) phase coupled with a "protracted" El Niño in 1782-84 that occurred during the event. ${ }^{28}$ According to Allan and D'Arrigo protracted episodes in the El Niño Southern Oscillation (ENSO) can be defined as “...periods of 24 months or more when the SOI [Southern Oscillation Index] and the Niño 3 and 4 CEP-EEP SST [Central Equatorial Pacific-Eastern Equatorial Pacific Sea Surface Temperature] indices were of persistently negative or positive sign, or of the opposite sign in a maximum of only two consecutive months during the period..."29 A 2009 study by J. Gergis and A. Fowler refined the standard to those events "...defined as persisting for three years or more..." 30

Such protracted episodes have not received anything like the degree of attention or research afforded to more "traditional" El Niño and La Niña events and their impacts and teleconnections. This is partly due to the insufficient number of such episodes during the historical record for a reliable statistical sample: not even twenty episodes of either phase have been resolved since 1850. Nevertheless, extensions of dynamical weather reconstructions (reanalyses) back into the $19^{\text {th }}$ century, plus the generation of more

${ }^{25}$ Robock, 2000; Santer et al., 2013; Ridley et al., 2015.

${ }^{26}$ Kington, 1980.

27 Grattan et al., 2005.

${ }^{28}$ D'Arrigo et al., 2011. A potential 20CR reconstruction of the atmospheric circulation over North Atlantic Europe region during and after the Laki eruption, as was done recently for the later Tambora and Krakatoa eruptions, is planned - Tambora (https://vimeo.com/120228702 has volcanic aerosol estimates from Tom Crowley; https://vimeo.com/120787915 has volcanic aerosol estimates from Gao, Robock, and colleagues (much larger amounts but timing is late; https://vimeo.com/120792719 has no volcanic aerosols and will serve as a "control" of what can be obtained from the sparse pressure observations alone), and the Krakatoa eruption was examined (https://vimeo.com/117533217

${ }^{29}$ Allan and D'Arrigo, 1999.

30 Gergis and Fowler, 2009. 
reliable historical documentary and palaeoenvironmental data and records before the instrumental period, are allowing for the resolution of more of these protracted episodes. Gergis and Fowler's 2009 study resolved two such episodes During the 1780s, a protracted El Niño from 1782-84 and a protracted La Niña from 1785-90. As noted above, the major El Niño and La Niña events of the 1780s are "embedded" within these longer episodes, which effectively cover much of this decade. ${ }^{31}$

Michael Chenoweth's 2003 study suggests that the years 1784-85 experienced a La Niña event, as indicated by Luc Ortlieb in 2000, and that its impact was felt in several parts of the globe. ${ }^{32}$ Geographer Georgina Endfield has provided evidence for droughts and frosts in Mexico in 1784 and 1785, potentially resulting from the "disturbed" weather patterns caused by this event. ${ }^{33}$ In the Caribbean, Chenoweth provides evidence for cooler Puerto Rico temperatures from coral proxies in the 1780-85 period, strengthened trade winds across Jamaica during the wet season in the 1780s, and incursions of cold air outbreaks from North America into the Caribbean during each of the winters in the 1781-84 and 1785-86 periods. Examining evidence from the New South Wales Colony, Gergis and Fowler's 2009 study indicates that 1788-1789 was a very wet year influenced by La Niña conditions. This was, in turn, followed by a severe El Niño drought spanning 1791-93.34 Grove's 2007 study refers to the Great El Niño of 1789-93.35 It is far more temporally extensive than "usual" El Niño events and coincides with the strong 1791-94 "protracted" El Niño episode. Nevertheless, there is debate in the literature on this topic. Some of this criticism relates to Grove's interpretation of terms in old textual material relating to India; other criticism points to discrepancies with palaeoenvironmental evidence regarding the nature, severity, and extent of Indian famines during this period. Edward Cook and colleagues state that "Much has been made of this drought's effect in India, with several references to severe famine there, but the MADA (Monsoon Asia Drought Atlas) does not suggest that it was any more severe over India than the other droughts... Although this could be due to limited tree-ring coverage in India itself, reconstructions over the entire Indian subcontinent have significant validation skill, and its more extreme occurrence in the southernmost part of India and near Sri Lanka is consistent with historical data from those regions. It is therefore possible that this drought was not uniformly severe over India and that other nonclimatic factors may have contributed to the severity of the societal consequences." 36

A 2014 study by David Nash and George Adamson demonstrates that the monsoon onset over western India was early in the first half and slightly later in the second half of

\footnotetext{
31 Gergis and Fowler, 2009.

32 Chenoweth, 2003; Ortlieb, 2000.

33 Endfield, 2008.

${ }^{34}$ Gergis and Fowler, 2009.

35 Grove, 2007.

${ }^{36}$ Cook et al., 2010.
} 
the 1780s. ${ }^{37}$ The figure below, by F. Shi and colleagues shows evidence for drought during major periods of famine in Indian history, including the 1780s. ${ }^{38}$ The question is whether the palaeo/proxy data so far available are of sufficient coverage and resolution in space and time to judge how extensive these droughts actually were across the region. The impact of these climate anomalies in some of these regions are considered in detail in the following sections.

$<<$ Insert Figure 2 >> < <aption: Time series of the reconstructed South Asian summer monsoon index (SASMI) (red line), the decadal (cyan line) and annual (blue line) inverse of dust concentrations in [an] ice core record, the inverse of the $\delta 180$ speleothem record (green line), and the tree-ring chronologies from Mae Hong Son (MHS) (black line) and Bidoup Nui Ba National Park (BDNP) (orange line) before AD 1670 (a) and after AD 1671 (b). The grey periods indicate the 26 famine events identified in India over the past millennium. ${ }^{39}$ Source: Shi, Li and Wilson (2014).>>

\section{Case Study 1}

\section{Famines in India, 1780-1812}

This case study focuses on India, and aims primarily to contextualise Roxburgh's report, as utilised by Grove. By exploring archival material held at the British Library India Office it builds a more nuanced, regional picture of the societal impact of this particular ENSO event across the subcontinent. Since both Gergis and Fowler and Allan and D'Arrigo have argued in favour of even more protracted ENSO episodes stretching from 1785-90 (La Nina) and from 1791-94 (El Niño), the period addressed is extended to include these years.

of particular interest is that storms and typhoons in India became more noticeable in this period. Most usually tropical cyclones in the Bay of Bengal occur from April to June and again from September to November. The major storm event of the 1780s occurred on 20 May 1787, when a cyclone in the Bay of Bengal struck the Indian coast near Coringa in Andhra Pradesh resulting in some 20,000 deaths. ${ }^{40}$

Two EIC reports are of particular interest in this regard. Both were compiled in the mid- to late $19^{\text {th }}$ century from contemporary accounts sent from various regions of the subcontinent to the East India House in London, and both concerned the prevalence of famine in India over the preceding century, since the expansion of EIC power, showing that concern over famine was obviously high at the time. First, in A Century of Famines F.C. Danvers presented a chronology of famine in India. He observed, "it is an appalling fact that during the past hundred years one part or another of India has been visited by famine

\footnotetext{
37 Nash and Adamson, 2014.

${ }^{38}$ Shi et al., 2014.

${ }^{39}$ Shi et al., 2014.

40 Patnaik and Sivagnanam, 2007.
} 
on no less than thirty-four...occasions." 41 His chronology for 1770-1812 is presented in summary form below, along with a map of areas affected by famine.

The great Bengal famine of 1770, an El Niño year, killed 10 million people. Its causes included the taxation policy of the East India Company.42 It was followed by the famines of the 1780s that Danvers recorded in some detail. The decade was to prove particularly unsettled. There was general scarcity in 1781-83 in the Carnatic and the Settlement of Madras, caused primarily by Hyder Ali's incursions. Government action to provide food was considered to have helped alleviate the situation, and the scarcity was essentially over by early 1783 . During 1782-84, the districts of Thurr and Parkur in Sind (then Western India; now Sindh, Pakistan) suffered the burning of crops and suspension of cultivation due to hostilities associated with the end of the Kulhora dynasty. These disasters combined with a two-year drought to produce famine..$^{43}$

Again in 1783-84 Behar, Purneah, Bheerbhoom, and parts of Rajeshye, the Northwest Provinces, and the Punjab experienced famine. Although Danvers noted that information was limited, since much of the affected territory was not under British rule, "there are reasons to believe that the upper parts of Hindustan had been visited with extraordinary drought during the previous years. In September and October 1783 there was an abnormal cessation of rain and extreme drought, and in the latter month a terrible famine was reported in all the countries beyond Lahore to Karumnasa (the western boundary of Behar)...the famine had already been severely felt in all districts toward Delhi. To the northward of Calcutta the crops upon the ground had been scorched, and nearly destroyed." By early 1784, the famine was over. ${ }^{44}$ Interestingly, Danvers observed that "as usual, the long drought was succeeded by great floods." The great Chalisa famine (literally, "of the fortieth") of 1783-84 in South Asia is recorded as having killed nearly 11 million people. It is said to have followed the unusual El Niño, which caused drought events and affected many parts of northern India from Kashmir to Punjab in the north to Rajasthan in the west and Uttar Pradesh in the East. Famine in the previous year 1782-83 had extended over South India including Madras under the English East India Company and Mysore under Haider Ali and Tipu.

The next Indian famine occurred in 1790-91, affecting the regions of Western India, Omerkot, Kach, Ahmedahad, Rewa Kanta, Broach, Surat, Kulladghi, Dharwar, Sawunt Warree, Kaira Belgaum, Rutnagheri, Pahlunpoor, Mahee, Kanta, and Baroda. Here Danvers emphasised the regionality of the famine ("in some of these districts famine was only partial and local") and the variety of causes, such as in Kach, where "famine was caused by innumerable black ants which swarmed in almost all parts of the country and destroyed vegetation." Again the lack of full information is noted: "very little is known concerning the

\footnotetext{
${ }^{41}$ Danvers, $1877,1$.

42 Damodaran, 2015.

${ }^{43}$ Danvers, 1877, 21.

${ }^{44}$ Danvers, 1877, 21.
} 
famine in many districts named (above), beyond the fact that in 1790 tradition records the occurrence of a very severe famine. An almost total failure of rains was the immediate cause, apparently, of the calamity, and sufficient information exists to prove that it was one of the most remarkable on record. So great was the distress that many people fled to other districts in search of food, whilst others destroyed themselves, and some killed their children and lived on their flesh." 45

Danvers also reported famine in South India during 1790-92. "[I]n these years there was a very serious dearth in the northern districts of the Madras presidency, and the pressure was apparently felt for about two years...from November 1790 to November 1792. Many deaths from starvation occurred. At an early period the Government suspended the import and transit duties on all kinds of grain and provisions, and imported grain from Bengal. In the latter part of 1791 the export of rice from Tanjore was prohibited except to distressed districts. Rice was distributed gratuitously by government and relief was afforded by employing the poor on public works." 46 Up to half the population perished in some districts of the Madras Presidency, such as in the Northern Circars. In other areas, such as Bijapur, although no records were kept, both the famine and the year 1791 came to be known in folklore as the Doji bara (also Doĝi Bar), or the "skull famine," on account, it was said, of the "bones of the victims which lay unburied whitening the roads and the fields." ${ }^{7}$ The famine also affected areas outside British rule including Hyderabad, Southern Maratha Kingdom, Deccan, Gujar, and Marwar-then all ruled by Indian rulers (Imperial Gazetteer, 1907). As in the Chalisa famine of a decade earlier, many areas were depopulated by mortality or migration. According to Grove, a total of 11 million people may have also died during the years 1789-92 as a result of starvation or accompanying epidemics. 48

Famines are also recorded in 1802-04 in Guzerat, Kach, Pahlunpoor, Rewa Kanta, Surat, Candeish, Ahmednagar, Poona, Sattara, Sholapur, Kolapur, Belgaum, Dharwar, Colaba, Ratnagherry, and the Nizam's Dominions; in 1803-04 in Moradabad, Bareilly, Etawah, Furruckabad, Cawnpore, Allahabad; in 1804-07 in Tanjore, North and South Arcot, Nellore, Chingleput, the Ceded Districts, and Trichinopoly; and in 1812-14 in Madura. However, for this period, the tone of the various details of the famines suggests that those of 1790-91 and 1790-92 were the worst on record, both in extent and severity of societal impact.

Danvers' report is interesting not merely as a source on meteorology and famine chronology in India. He has much of interest to say that allows us to see in proper proportion the significance of rainfall variation within a larger causal framework, and how such variation is linked to famine. Danvers stated that "famines in India have arisen from several different causes...the most general cause has been the failure of rains. Distress has

\footnotetext{
45 Danvers, 1877, 22.

46 Danvers, 1877, 22-3.

47 Elliot, 1863.

48 Grove, 2007.
} 
also, however, been caused by hostile invasions; by swarms of rats or locusts" or ants in the case of the 1790-91 famine in Kach, described above, "by storms and floods; and not infrequently by the immigration of starving people from distant distressed parts, into districts otherwise well provided with food supplies; and excessive exports of grain into famine stricken districts, or by combination of two or more of the above named circumstances." ${ }^{\prime 9}$ However, Danvers' key but perhaps counter-intuitive observation (predicting Amartya Sen) is that most deaths in times of famine were not caused by actual shortage of food: "It is an important fact," he states, "that famines in India are more generally famines of work than of actual absence of food throughout any large extent of the country." ${ }^{50}$ Danvers' point then is that the causal link between lack of rains and famine is more complex than might be assumed. The problem is not that local harvests are poor and therefore food is in short supply when rains are insufficient. It is more that lack of rain disrupts agricultural employment patterns and leaves poor workers without sufficient money to purchase food.

Danvers continued on this topic to describe how, "from a study of the history of past famines it appears that these visitations are almost as liable to be caused by unseasonable rains, or by their unequal distribution, as by deficient amount of rainfall during the year." He concludes by stating that "there are altogether so many circumstances connected with rainfall and its influence on the crops that it is difficult to arrive at any definite conclusion as to the actual proportionate deficiency of rain that would constitute a famine drought." 51

A glance at Danvers' map of areas affected by famine (here reduced from its original coverage to the period 1770-1825 only) shows the asymmetry of famine distribution. Even this half-century of frequent famines displays vast areas that remained completely immune. Danvers' map then, much like his report, points to a markedly complex relationship between deficient rains and significant social impact.

$<<$ Insert Figure 3>> <<Caption: Map of famine areas in India from 1770-1825, copied from F.C. Danvers, A Century of Famines. ${ }^{52>>}$

The other source on Indian famines, George Campbell's Extracts from Records in the India Office Relating to Famines in India 1769-1788 (BL IOR V/27/830/14) was published in 1868. First, it gives details of the famine around Madras in 1782, primarily driven by warfare in the area: "when the enemy was at their walls, and by his ravage, in every part of the adjacent country, had destroyed the cattle and reduced the inhabitants to the most pressing difficulty to obtain the common necessaries of life." A note from Bengal in the 1783-84 famine is particularly interesting for the light it shines on the experience and

\footnotetext{
${ }^{49}$ Danvers, $1877,1$.

${ }^{50}$ Danvers, 1877, 2.

51 Danvers, 1877, 2.

52 Danvers, 1877, 12.
} 
cultural construction of drought, famine, and scarcity in the region and the period. A letter describes how the "shocking experience" of the 1770 famine "still fresh in the memories of most people" combined with the shipment of vast quantities of grain to Madras in the preceding seasons again left Bengal vulnerable to artificial shortages. ${ }^{53}$

Perhaps the most valuable section of this collection is the details of the famine and general upheaval caused by a series of storms in 1787. Several sources reported on this event: An article in The Nautical Magazine recorded that "Captain Huddart describes one [storm] which destroyed ten thousand persons in the neighbourhood of Coringa, in May, 1787, and penetrated twenty miles over the country."54 William Roxburgh (1832: 34) noted a major loss of his papers, including those on various plant species in his collection, as a result of this event. 55 "I had made and noted down many observations on its uses, when in large practice in the General Hospital at Madras in 1776, 77 and 78, but lost them, with all my other papers, by the storm and inundation at and near Coringa in May 1787."

The Madras typhoon of May 1787 was part of a series of very severe storms occurring throughout the year in Bengal. Reports of floods from the General Letter from India of $15^{\text {th }}$ December 1787, describe a "violent inundation" of which the author states that "no memory can recollect any preceding instance of similar inundations [...\} the distress occasioned by the inundation was aggravated by a storm which happened on the $2^{\text {nd }}$ ultimo, [i.e., November] and which, wherever it prevailed, destroyed much of the existing crops. ${ }^{\prime 56} \mathrm{An}$ important point here with regard to the meteorological record is that the second storm (along with others described below), which occurred in November, exacerbated the already difficult situation caused by the Typhoon in May. This second disaster made the problems associated with the first much more difficult to recover from. The governor general Lord Cornwallis was suspicious of false claims, warning that "it will be the duty of the board of revenue to make the most scrupulous investigations, and to reject every ill-founded claim for deductions." Again an embargo on export was put in place, now for six months. ${ }^{57}$ More disparities are seen in the aftermath of the flood and storms. Grain prices were very high in Moorshedabad and Dacca in particular "where sufferings of the poor inhabitants were the greater," but much more normal in Benares and Behar "where the crops had been abundant"; thus exports from these regions to the affected areas were encouraged. In addition to the Madras event in 1787-88, other reports recorded early and abnormally heavy rains in Bengal and Behar. Through "the latter part of March to the latter half of July, they had continued with such violence as almost to

\footnotetext{
53 Campbell, 1868, 114-5.

54 The Nautical Magazine, 1832, 293.

${ }_{55}$ Roxburgh, 1832, 34.

${ }^{56}$ Campbell, 1868, 142.

${ }^{57}$ Campbell, 1868, 141.
} 
render cultivation impossible." A government-imposed ban on grain exports was credited with resolving the situation by June of 1788.58

By 1 June 1788, the General Letter could state "that the distresses which have been suffered by the scarcity of grain, in different parts of the country and particularly in Dacca, have been of late much relieved." The proceedings of the revenue board reveal the internal conflict over the continuation of collections through times of scarcity. As shown above Cornwallis was resigned to the fact that remission would be necessary, but aimed to scrupulously investigate any suspected false claims. W. Hindman, an acting collector, wrote on July 20,1787 that since the $11^{\text {th }}$, "rains have continued with a violence hitherto unknown, and, it grieves me to inform you, that by the advice I have received from the Mofussil [rural areas], I am apprehensive of a total depopulation of all the pergunnahs [subdistricts], if the weather does not soon moderate...about two thirds of the ryots [peasants] have retired for safety with their families to the hills and others are following daily, whole villages have been swept away." He continued, "it is impossible for language to convey the distressful situation of this province; where ever you go you see nothing but a sheet of water, with here or there the tops of houses and trees. Whole crops have been levelled and villages, cattle, grain, and implements of husbandry swept away. Many of the inhabitants have been drowned and whole pergunnahs deserted...the small islands before the city of Dacca are entirely overflowed, and only a few of the tops of the houses are to be seen, the oldest inhabitants remember nothing like it.... The overflowing banks of the Berhamputer [Brahmaputra], a circumstance never known before, has certainly occasioned this dreadful inundation." ${ }^{59}$ The collector of Chittagong reported that "the deluge of rain which has recently fallen in these parts exceeds, I am given to understand, the memory of the oldest inhabitants." 60

Campbell's collection shows how very severe weather difficulties-again and again made worse by repeated storms, and very likely combined with administrative determination to continue tax collection to the greatest possible extent-left great want and dislocation amongst the poor. The collector of Nuddea wrote in September 1787 that "the rivers which run through this district have risen to so alarming a height that I should consider myself deficient in my duty did I omit to communicate the intelligence to you; the Jellingy in particular, which passes by this place has swelled to such a degree that there are few parts where its banks are not overflowed on both sides and to judge from my own observation and the opinion of people here, it must be at least two feet higher than it was in the rains of 1785, and then it was higher than the oldest inhabitants had ever remembered it." At the end of that month "vast torrents" were recorded in Midnapore by which "those poor creatures that survived the calamity have lost everything in the world." ${ }^{1}$ Similar

\footnotetext{
58 Danver, 1877, 21.

${ }^{59}$ Campbell, 1868, 152.

${ }^{60}$ Campbell, 1868, 147-53.

${ }^{61}$ Campbell, 1868, 175-7.
} 
reports came from Burdwan, Sarun in the West to Sylhet and Rungapore in the East. ${ }^{62}$ Numerous collectors wrote the Board of Revenue warning that the population could not support regular tax collections. In some cases the Board permitted collectors to exercise discretion, but in other cases remittance was refused.

Danvers' and Campbell's collections of famine reports appear to show a significant increase in climate-related societal difficulties during the 1780s-90s. Although the 1770 famine was extremely severe, no other famines are described for the remainder of the 1770s, whereas a total of six notable famines are described between 1780 and 1791(including the Doji Bara and Chalisa famines), none in the remainder of the 1790s, two in the 1800s, and two in the 1810s. All of the 1780s famines were in part born of climatic irregularities, although as described above, through notably complex causal links. The most frequent climatic contribution was lack of rain, but disruptions to the expected timing of rain, excessive rain, and a notable season of extreme storms, floods, and intense winds in 1787 also contributed to famine when they occurred. Campbell's collection of reports on the storms of 1787 add much detail to previous knowledge of the May typhoon and suggest that areas of Bengal were struck repeatedly by dramatic storms and floods of an extent not known in living memory. Such reports appear to support Alan's and Gergis's suggested identification of a more extended La Niña episode beginning in mid-decade.

Although statistical data are absent, Danvers' qualitative assessment of the 1790-92 famines suggests they were the most severe of the period. However, it would be impossible from the information contained here to assess their impact in relation to the 1770 famine, which Campbell in 1868 - with the benefit of hindsight-interestingly referred to as "the Great Famine of 1770." Several types of evidence not found elsewhere indicate that at least in some regions the 1790-92 famine was remarkable in its impact, thus supporting Grove's identification of intense ENSO activity at this time. ${ }^{63}$ These include: reports of direct governmental famine relief through the distribution of rice, the institution of employment programmes through public works, subjective judgments of its extreme severity, descriptions of the failure of rains, and of resort to suicide and eating of children.

\section{Case Study 2}

The Influence of Climate on the First European Settlement of Australia, 1788-93 Aside from some pioneering works of $19^{\text {th }}$-century scholars, until recently Australian historical records remained essentially unexploited for use in contemporary climate research. ${ }^{64}$ From 2009-12, an initiative known as the South Eastern Australian Recent Climate History (SEARCH) project (www.climatehistory.com.au) used historical documents along with meteorological and paleoclimate data to reconstruct climate variability back to

\footnotetext{
${ }^{62}$ Campbell, 1868, 185.

63 Grove, 1998.

64 Jevons, 1859; Russell, 1877.
} 
first European settlement in 1788 \{see chapter 3.7\}.65 One of the aims of the research was to identify previously undescribed wet and dry periods in the pre-1900 period and examine any possible relationship with large-scale circulation modes, such as the ENSO phenomenon, that influence the region. ${ }^{66}$

Extreme phases of the ENSO cycle frequently result in extreme weather conditions around a large part of the globe. ${ }^{67}$ In the western Pacific, El Niño events increase the likelihood of severe drought, while La Niña conditions favour the above-average rainfall and flooding. 68 Typically, the reverse is true in the Eastern Pacific, where El Niño episodes bring heavy rainfall. 69

Recent advances in reconstruction of past ENSO conditions now incorporate data from the western Pacific, rather than traditional historical El Niño chronologies that only incorporated historical records from South America. ${ }^{70}$ They have also reconstructed historical La Niña events for the first time. In contrast with Grove, Gergis and Fowler conclude that a very strong La Niña event (not El Niño) was centred on 1788 and spanned to 1790 . A characteristic "phase flip" seems to have occurred in 1791, beginning a strong El Niño event that lasted until $1793 .{ }^{71}$

Evidence for the 1788-90 La Niña then 1791-93 El Niño event sequence is found in the recently consolidated climate record for southeastern Australia (SEA). ${ }^{72}$ While it is clear that ENSO influences rainfall variability in the broader SEA region, the signal recorded in coastal New South Wales is weak but still discernible for high magnitude events. $^{73}$

When Governor Arthur Philip arrived with the First Fleet in January 1788, Sydney was in the middle of a wet summer. The colony's chief bureaucrat, David Collins, meticulously recorded weather conditions, the first of which reads: "The weather during the latter end of January and the month of February was very cold, with rain, at times very heavy, and attended with much thunder and lightening, by which some sheep, lambs and pigs were destroyed." 74

More "inclement, tempestuous weather" persisted throughout the winter of 1788 making life in the new colony difficult. Collins wrote: "During the beginning of August much heavy rain fell, and not only prevented the carrying on of labour, but rendered the work of much time fruitless by its effects; the brick-kiln fell in more than once, and bricks to a large

\footnotetext{
65 Gergis et al.,2009; Gergis et al., 2010; Ashcroft et al., 2012; Fenby and Gergis, 2012; Gergis and Ashcroft, 2013; Ashcroft et al., 2014a; Ashcroft et al., 2014b.

${ }^{66}$ Risbey et al., 2009.

${ }^{67}$ Diaz and Markgraf, 2000.

${ }^{68}$ Risbey et al., 2009.

${ }^{69}$ Allan et al., 1996.

70 Gergis and Fowler 2009; Quinn, 1992; Quinn and Neal, 1992; Ortlieb, 2000.

${ }^{71}$ Gergis and Fowler, 2009.

${ }^{72}$ Gergis et al., 2010; Fenby and Gergis, 2013; Gergis and Ashcroft, 2013.

${ }^{73}$ Gergis and Ashcroft. 2013.

${ }^{74}$ Collins, 1798.
} 
amount were destroyed; the roads about the settlement were rendered impassable; and some of the huts were so far injured as to require nearly as much time to repair them as to build them anew. It was not until the $14^{\text {th }}$ of the month, when the weather cleared up, that the people were again able to work."

By the second year of settlement, the foreign landscape and erratic weather were wreaking havoc on the establishment of agriculture in Sydney. In February 1789 the young colony was still experiencing wet conditions, making life increasingly desperate. Collins reported: "the weather was extremely unfavourable; heavy rains, with gales of wind, prevailing nearly the whole time. The rain came down in torrents, filling up every trench and cavity which had been dug about the settlement, and causing much damage to the miserable mud tenements which were occupied by the convicts." ${ }^{75}$

Unsettled conditions appear to have persisted into autumn 1790. As Sydney endured more flooding, soon they learned of the devastating loss of the cargo ship HMS Sirius on Norfolk Island on 19 March $1790 .{ }^{76}$ When the HMS Supply brought news of the wreck of the Sirius, the mood of the colony sunk deeper into despair. As Collins recalled: 'The weather had been very wet during this month; torrents of rain again laid every place under water; and many little habitations, which has withstood the inundations of the last month, now suffered considerably." 77

The loss of the Sirius brought Sydney Cove to the brink of famine, and drastic ration reductions were enforced. Collins wrote, "it was unanimously determined, that martial law should be proclaimed; that all private stock (poultry excepted) should be considered as property of the state...the general melancholy which prevailed in the settlement when the above unwelcome intelligence was made public, need not be described; and when the Supply came to an anchor in the cove everyone looked up to her as to their only remaining hope...it was determined to reduce still lower what was already too low...very little labour could be expected from men who had nothing to eat." ${ }^{\prime 8}$ Cold and hungry, many feared the weakened colony was in danger of collapse.

By September 1790, the weather started to improve. Soon, however, the colony faced a particularly dry summer. On 27 December 1790, Watkin Tench described the first European account of a summer heatwave in Sydney, likening the northwest wind to the "blast of a heated oven." Tench also described the impact of the dry conditions on the food supply: "vegetables are scarce...owing to want of rain. I do not think that all the showers of the last four months put together, would make twenty-four hours rain. Our farms, what with this and a poor soil, are in wretched condition. My winter crop of potatoes, which I

\footnotetext{
75 Collins, 1798.

${ }^{76}$ Hunter, 1793.

77 Collins, 1798.

78 Collins, 1798.
} 
planted in days of despair (March and April last), turned out very badly when I dug them about two months back. Wheat returned so poorly last harvest."79

Early in 1791 Governor Philip wrote: "the dry weather still continued, and many runs of water which were considerable at this season the last year [1790], were now dried up...at Sydney, the run of water was now very small." ${ }^{80}$ David Collins commented on the heat stress on the local wildlife: "Fresh water was indeed everywhere very scarce, most of the streams or runs about the cove being dried up. At Rose Hill [Parammatta], the heat on the tenth and eleventh of the month, on which days at Sydney the thermometer stood in the shade at $105^{\circ} \mathrm{F}\left[40.6^{\circ} \mathrm{C}\right]$, was so excessive (being much increased by the fires in the adjoining woods), that immense numbers of the large fox bat were seen hanging at the boughs of trees, and dropping into the water...during the excessive heat many dropped dead while on the wing... In several parts of the harbour the ground was covered with different sorts of small birds, some dead, and others gasping for water." ${ }^{11}$ Governor Arthur Philip elaborated on the staggering scale of the scene: "from the numbers that fell into the brook at Rose Hill [Parramatta], the water was tainted for several days, and it was supposed that more than twenty thousand of them [bats] were seen within the space of one mile." 82

In contemporary Sydney, autumn and winter rains are important for recharging reservoirs and rejuvenating parched land. The failure of these rains can have a devastating effect on agriculture as it did in the late $18^{\text {th }}$ century. In April 1791, Arthur Philip remarked that "the dry weather continued...the quantity of rain which fell in the month of April [1791], was not sufficient to bring the dry ground into proper order for sowing the grain... this continuance of dry weather, not only hurt their crops of corn very much, but the gardens likewise suffered greatly; many being sown a second and a third time as the seed never vegetated, from want to moisture in the soil." ${ }^{33}$ As a result of the drought, Governor Philip tightened rations as the food supply of the struggling colony began to dwindle: "Little more than twelve months back, hogs and poultry were in great abundance, and were increasing very rapidly...but as this time [April 1791] there was seldom any to sell." Watkin Tench lamented, "I scarcely pass a week in summer without seeing it rise to 100 degrees [Fahrenheit-i.e., $\left.37.8^{\circ} \mathrm{C}\right]$; sometimes to $105\left[40.6^{\circ} \mathrm{C}\right] .{ }^{\prime 84}$

David Collins left a description of the dry conditions that persisted into June 1791: "...the ground was so dry, hard and literally burnt up, that it was almost impossible to break it with a hoe; and until this time there has been no hope or probability of the grain vegetating." ${ }^{85}$ On returning back from Norfolk Island John Hunter, ex-Captain of the

\footnotetext{
79 Tench, 1789.

${ }^{80}$ Collins, 1798.

81 Collins, 1798.

82 Hunter, 1793.

${ }^{83}$ Hunter, 1793.

84 Tench, 1789.

85 Collins, 1798.
} 
doomed Sirius, described the scene at Sydney Cove: "all the streams from which we were formerly supplied...were entirely dried up, so great had been the drought; a circumstance, which from the very intense heat of summer, I think it probable we shall be frequently subject to." 86

By November 1791, the worsening drought led to the first documented account of water restrictions imposed on Sydney. The small freshwater stream that ran into Sydney Cove proved an irregular source of water. To try and control the amount of water flowing out of the colony, "holding tanks" were cut into the sandstone banks to provide storage for the water. Collins wrote: "By the dry weather which prevailed the water had been so much affected, besides being lessened by the watering of some transports, that a prohibition was laid by the Governor on the watering of the remainder of Sydney... to remedy this evil, the Governor had employed the stone-mason's gang to cut tanks out of the rock, which would be reservoirs for the water large enough to supply the settlement for some time." 87 This became known as the "tank stream," and is likely to be the earliest example of water regulation in Australia's colonial history.

From August 1794 onwards there are reports that conditions in the settlement gradually improved as the grip of drought loosened: "Notwithstanding the weather was unfavourable during the whole of this month, the wheat every where looked well, particularly at the settlement near the Hawkesbury," Collins remarked. ${ }^{88}$ By January 1795, he commented on the agriculture now beginning to thrive as heavy rains began to soak the floodplains of the Hawkesbury River. The first major drought experienced by Australia's European settlers had finally come to an end, but it would later come to be recognised as representing the quintessential ENSO cycle of drought and flooding rains that still defines life in $21^{\text {st-century Australia. }}$

\section{Case study 3}

\section{Regional Events and Impacts during the 1780s in Japan}

In Japan, the 1780s were one of the most disastrous periods in historical times. The great "Tenmei" Famine led to the deaths of around a hundred thousand people due to extremely poor summer rice harvests across northern and eastern Japan, particularly in 1783-84 and 1786. The primary cause of the famine and harvest failures was the exceptionally cool weather during the summers of 1783 and 1786 . Under present conditions, generally hot summers are experienced in Japan under the influence of strong subtropical highs, which bring dry and sunny weather conditions. Cool summers occur under the influence of stagnant polar fronts and passing extra-tropical cyclones, which bring cloudy and rainy conditions.

\footnotetext{
${ }^{86}$ Hunter, 1793.

${ }^{87}$ Collins, 1798.

${ }^{88}$ Collins, 1798.
} 
Although instrumental meteorological data is not available for this period, several attempts have been made to estimate summer temperatures in the 1780 s based on daily weather diaries in Japan. ${ }^{89}$ These include the Ishikawa diaries, which are continuous family diaries kept in the western suburbs of Tokyo from 1721 to $1940 .{ }^{90}$ Using these diaries, researchers have categorized weather patterns in Japan into several types, based on the number of days with rain in the months of July and August. The "no rain across Japan" weather pattern had its lowest frequency (8 days) in 1783 and the second lowest (9 days) in 1786, in contrast with the highest (33 days) in 1781 and 1789 and the second highest ( 32 days) in 1785 . This suggests that the weather and climate in 1780 s were unstable, with large year-to-year variability of weather patterns, and that 1783 and 1786 were extremely rainy and cool.

Since the number of rainy days is highly correlated with the mean temperature in a summer month, especially in July (the correlation coefficient is -0.70 based on the Japan Meteorological Agency data for 1876-1940), it is possible to reconstruct July temperatures in Tokyo for the period 1721-1940 based on the weather records in the Ishikawa diaries. The reconstructed temperature series show several cooler and warmer periods. From 1721 to 1790 , temperatures are estimated to have been about 1 to $1.5^{\circ}$ lower than at present, and July temperatures show large year-to-year variability with the lower values below $22^{\circ}$ in $1728,1736,1738,1755,1758,1783,1784$, and 1786 . Temperatures in the 1780 s were often very low with large inter-annual variations. In the summer of 1783 , exceedingly cool and wet conditions brought an extremely poor rice harvest, and this unusual weather led to a severe famine in Japan. The $19^{\text {th }}$ century brought warmer periods during the 1810s and early 1850s. By contrast the 1830s, late 1860s, and late 1890s were relatively cool, and great famines occurred in the 1830 s as they had in the $1780 \mathrm{s.}{ }^{91}$

<<Insert Figure 4 here >> <<Figure 4 caption: Time series of reconstructed (blue lines) and observed (black/gray lines) July temperatures in Tokyo for 1721-2000. Thin lines indicate year-to-year variations and thick lines indicate 11-year running mean. The blue rectangular part indicates the period of the 1780s. Modern Tokyo has a very strong urban heat island effect and this is likely to have contributed to warming evident in the 20th century. Figure modified and updated from Mikami (1996). >>

The weather and climate during 1780s can be summarized as follows:

Summer 1781

Hot summer conditions across Japan with extremely dry conditions in southwestern Japan. Summer 1782

Temperatures were basically as usual across Japan.

\footnotetext{
${ }^{89}$ Mikami, 1983; Mikami, 1987.

${ }^{90}$ Mikami, 1996; Mikami, 2008; Zaiki et al., 2012.

91 Mikami, 1996; Mikami, 2008; Zaiki et al., 2012.
} 
Summer 1783

Extremely cool and wet conditions across Japan with exceptional rainfall in northeastern Japan.

Summer 1784

Slightly warm in northern Japan and wet/cool weather in southern Japan.

Summer 1785

Hot summer conditions across Japan with dry weather patterns in western Japan.

Summer 1786

Extremely cool summer conditions across Japan centred in the western area with much rainfall.

Summer 1787

Rainfall amounts were as usual across Japan, with high temperatures.

Summer 1788

Usual temperatures across Japan; slightly wet in western Japan and less rainfall in northern Japan.

Summer 1789

Almost normal weather conditions across Japan with hot summer climate in northern Japan.

Summer 1790

Hot and dry weather conditions across Japan.

The government took several relief measures, such as promoting emergency rice stocks in local governments and reducing of the price of rice. Nevertheless, mortality rose dramatically during the severe famines of the 1780s. Starved people in rural areas sought food in towns and cities, where destructive urban riots occurred.

\section{Case Study 4}

\section{Africa (including Egypt)}

The explosion of the Laki volcanic fissure in Iceland between the summer of 1783 and the winter of 1784 had a direct impact on rural Egypt. ${ }^{92}$ Laki's explosion produced a heavy $\mathrm{H}_{2} \mathrm{SO}_{4}$ aerosol burden in the Arctic north, which led to "substantial heating of the Arctic atmosphere and subsequent reduction of the equator-pole thermal gradient." 93 The result was a weaker westerly jet stream of warm air, which contributed to a strong dynamical effect of lessening the African and Indian Ocean monsoon circulations.

The Indian Ocean monsoons fed the Nile. Moving over the Ethiopian highlands in early summer, these rains swelled the upper reaches of the Nile system, eventually flowing into Egypt in June. The river rose in the south at Aswan in June and in Cairo by July,

92 Mikhail, 2015.

93 Thordarson and Self, 2003. 
peaking in the capital in late August or early September. The Lakagígar eruption took place in June-just in time to interrupt the Indian Ocean summer monsoons. Climatological studies make clear that the Lakagígar eruption led to reduced Nile floods in 1783 and 1784. Estimates are that the Nile's flow decreased by as much as $18 \%$ in these years. ${ }^{94}$

The summer of 1783 brought the lowest flood and that of 1784 the third lowest of the entire period from 1737 to $1800 .{ }^{95}$ The Nile was the literal lifeline of Egypt, its ultimate source of food, revenue, and power. ${ }^{96}$ Thus a reduction of nearly a fifth of its waters obviously had devastating consequences for the social, economic, and political structures built by the wealth the Nile produced.

The sources from this period make clear that the eruption's effects on Egypt precipitated a massive crisis in the countryside. Documenting the early fall of 1783, the Egyptian chronicler 'Abd al-Rahman al-Jabartī wrote of the Nile's dearth that year and the food shortages that followed. "The Nile did not rise sufficiently, and it fell rapidly... The ground remained dry in the South as well as the north. Grain became scarce... The price of wheat was on the loose...and the poor suffered greatly from hunger." ${ }^{\prime 97}$ Almost a year later, another lack of summer floods exacted a similar toll on Egyptians, leading to great "kaht $\ddot{u}$ gala" (scarcity and dearth). ${ }^{98}$ The chronicler al-Jabartī wrote that the fall of 1784 was "like the preceding one with distress, rising prices, an inadequate rise of the Nile, and continual internal strife." 99

Two consecutive years of poor floods ravaged the countryside, Egypt's economy, and its rural social structure. Land became so progressively unproductive that the taxes garnered from rural Egypt in 1785 were the second lowest total in over sixty years. "The land turned to waste," "peasants abandoned their villages because of a lack of irrigation," and "many of the poor starved to death." 100 Moreover, "store-houses on the river stayed empty of grain for a whole year and the granaries also remained closed. People's daily bread and subsistence were cut off, and they perished regardless of whether they compromised or cheated." 101 Travelling in Egypt in these years, the French philosopher and orientalist C. F. Volney corroborated al-Jabartì's description: "the inundation of 1783 was not sufficient, great part of the lands therefore could not be sown for want of being watered, and another part was in the same predicament for want of feed. In 1784, the Nile again did not rise to the favourable height, and the dearth immediately became

\footnotetext{
94 Oman et al., 2006.

${ }^{95}$ Lyon, 1905.

96 Mikhail, 2011.

97 al-Jabartī, 1994.

98 Başbakanlık Osmanlı Arşivi, Hatt-ı Hümayun 28/1354 (7 Zilkade 1198/22 September 1784).

${ }^{99}$ al-Jabartī, II, 1994, 138.

100 al-Jabartī, II, 1994, 138.

101 al-Jabartī, II, 1994, 139-40.
} 
excessive."102 By the end of 1784, "many men and animals had perished from hunger."103 As evidence of just how hungry people had become, Volney reported seeing two men "sitting on the dead carcase of a camel, and disputing its putrid fragments with the dogs." 104

In Egypt (as in Iceland), drought and hunger in 1783 and 1784 made people more susceptible to plague and other diseases. ${ }^{105}$ Volney guessed that in these years "famine carried off, at Cairo, nearly as many as the plague."106 The plague began in the winter of 1783-84, with hundreds of dead bodies taken out of Cairo each day. It increased its deadly intensity in the summer and fall of 1784, likely because the previous years' food shortages had weakened rural people's immunities. ${ }^{107}$ It continued into 1785 . The combined famine, drought and disease continued into 1785 . The combined forces of drought, famine, and disease decimated rural populations through both death and flight. Citing "received opinion," Volney estimated that Egypt lost one sixth of its total population between 1783 and 1785.108

The environmental impacts of the Lakagígar eruption immediately contributed to the economic, political, and social transformation of rural Egypt. In the stress and confusion of drought, famine, depopulation, and disease, local powerbrokers throughout the countryside saw an opportunity for theft and a chance to tighten or extend their authority over territories and communities. Banditry, plundering, and violence thus gripped Egypt in the middle of the 1780s. ${ }^{109}$ "During this period," al-Jabartī wrote, "lawlessness increased." 110 Local elites and their henchmen looted cargo from ships on the Nile and from transport caravans on roads; exacted protection money from local communities; stole grain, animals, and cash; and destroyed crops. ${ }^{111}$ This violence, theft, and turmoil further encouraged rural depopulation as countless people fled these dreadful circumstances. "Extortions and acts of tyranny committed by the amirs [elites] followed one another, and their followers spread through the country to levy money from the villages and towns and invented illegal contributions...until they ruined the peasants, who became unable to bear the burden and abandoned their villages." ${ }^{112}$ Thus, the consequences of the ecological stress were a major component of the political and economic history of Egypt in the 1780s and 1790s.

\footnotetext{
102 Volney, II, 1798, 122

103 al-Jabartī, II, 1994, 128.

104 Volney, 1, 1798, 122.

105 Mikhail, 2008.

106 Volney, 1798, 122.

107 Başbakanlık Osmanlı Arşivi, Hatt-ı Hümayun 29/1361 (13 Şa'ban 1198/1 July 1784)

108 Volney, I, 1798, 122.

109 White, 2011.

110 al-Jabartī, II, 1994, 157.

111 al-Jabartī, II, 1994, 123, 133-4.

112 al-Jabartī, 1994, 138.
} 
Elsewhere on the continent of Africa, some meteorological information is available for nearly all of the 1780s. Historical sources-mainly from European observers-provide useful descriptions of meteorological conditions and human impacts, if not always the same level of context and detail found in the other parts of the world discussed in this chapter. For Morocco, Algeria, and Tunisia enough information is available in the sources consulted that the absence of reference to famine or drought is a likely indicator of good rainfall. A fair amount of information is available from the central and eastern Sahel and Guinea Coast, but it is somewhat ambiguous. Relatively little information is available for eastern and southern Africa.

The 1780s appeared to have been a relatively prosperous decade over much of North Africa. Charles Bois stated that this decade was part of a long period of prosperity in Tunisia, with harvests being so good that wheat was being exported from the region. ${ }^{113}$ The occurrence of plague in 1784 and 1785 could also imply good rainfall, since precipitation is correlated with plague occurrence in modern Africa. ${ }^{114}$ In Morocco, however, famine and drought occurred in 1780, 1781, and 1782. ${ }^{115}$ Algeria experienced bad harvests in 1784 and 1785, and a famine occurred near Oran, in western Algeria in 1786.

The most complete record from West Africa in the 1780s comes from the Cape Verde Islands, a region of summer rainfall similar to the Sahel. Good rainfall occurred in the years 1780-84, but drought and famine prevailed in much of the region from 1785-92.116 Drought was particularly intense from 1785 to 1787 . In Senegambia the 1780 s were primarily dry, and Charles Becker (1985) reports famine and/or food shortages in Senegal in 1782, 1784, 1786, 1787, and 1789. Low rainfall and drought occurred in Gambia and Guinea-Bissau in 1786, followed by famine in southern Gambia. In Sierra Leone, John Matthews (1788) reported that the rainy season in 1785 was more severe and longer than usual.

While droughts and anomalously wet years tend to affect the entire east-west extent of the Sahel, that may not have been the case in the 1780s. Chronologies for Chad, Agadez, Nigeria, and the Niger Bend region indicate only a single reference to relatively dry conditions during that decade. Plague was common in the region between the Niger Bend and the Voltas (Burkina Faso and Ghana) from 1786 to 1796, suggesting relatively wet conditions. ${ }^{117}$ This was supposedly a "time of plenty" in the Sudan, although a drought occurred in Darfur ca.1786 and the natives were forced to eat tree branches. Lake Chad, which is influenced by both Sahelian and equatorial rainfall, rose to very high levels. As a consequence, it was possible to travel by boat from the lake to the Tibesti region. Some

\footnotetext{
113 Bois, 1944.

114 Debien et al., 2010.

115 Mercer, 1974.

116 Almeida, 1997; Patterson, 1988; Brooks, 2006.

117 Ogot, 1992.
} 
reports suggest extremely wet conditions in the northern Sahel and Sahara. In $1780 \mathrm{a}$ great flood occurred in Agadez (central Niger). Rainfall continued from early morning to early afternoon and destroyed the town. A strong stream flowed in 1789 in Murzuq, but was later covered by advancing sands. ${ }^{118}$ For the more equatorial regions of the Guinea Coast and coastal Angola information on the 1780s is abundant. Much of it is found in correspondence related to the slave trade and supplemented by travellers' journals. ${ }^{119}$

A late onset of the rains and references to a scarcity of corn, including a famine in Dahomey, suggest that 1780 was relatively dry on the Guinea Coast. Dryness continued to cause trouble early in 1781 . The rains also started late but were prolonged, which greatly affected Europeans. In 1782 the rains were reportedly the worst experienced in many years. ${ }^{120}$ Heavy rainfall and rough seas were mentioned in March 1784, suggesting an early start to the rainy season. ${ }^{121}$ References to much sickness and anticipation of better weather suggest intense rains in 1785; however, references to dried-up water tanks in early 1786 imply that the rains were inadequate. Wetter conditions commenced in 1787 and prevailed throughout most of the 1790s. Heavy rains caused the fort at Sekondi (central Ghana) to fall down in 1787 and many houses to collapse again in 1788 and 1789, thus affecting both the British fort at Secondi and Danish fort at Christiansborg (Accra). ${ }^{122}$

The climate of coastal Angola is in some ways comparable to that of the Guinea Coast. Both regions are strongly influenced by temperatures in the nearby Atlantic. However, while rainfall peaks in June along the Guinea Coast, it peaks in March or April in coastal Angola and the boreal summer there is dry. A chronology compiled in 1982 by J. Miller indicates abnormally dry conditions in eight years of the 1780s, with drought occurring in four of those years (1786-89). The drought conditions continued into the early 1790s. Ample rainfall is mentioned for Luanda only in 1785.123

There is little historical information for the 1780s in eastern equatorial Africa. However, lake-level reconstructions suggest that, as in Angola, conditions were relatively dry. Lakes Malawi, Chilwa, Tanganyika, and Rukwa were relatively low, and Nile minimum levels suggest that Victoria was likewise low. ${ }^{124}$ During this decade a famine occurred in the lakes region of East Africa that was so severe that large-scale migrations occurred.125 At the same time the levels of Lake Naivasha were falling, further suggesting dry conditions. ${ }^{126}$

\footnotetext{
118 Nicholson, 1980.

119 Nicholson, 1980; Norrgård, 2013; Norrgård, 2015.

120 Miles, 1782.

121 Watts, 1784; Morgue, 1784.

122 Norris, 1787.

123 Miller, 1982.

${ }^{124}$ Nicholson, 1998a; Nicholson, 1998b; Nicholson, 2000.

125 Ogot, 1992.

126 Verschuren et al., 2000.
} 
Tree-rings from the winter rainfall region of South Africa suggest that the 1780s was probably the wettest decade since the late sixteenth century. ${ }^{127}$ Tree-rings also suggest that wetter conditions occurred in Natal. An absence of drought references in the 1780s, despite references to drought in the 1770s and 1790s suggest that rainfall was also adequate in Zambia, Zimbabwe, and Mozambique. Southern Namibia appears to have been relatively drought-free in the 1780s. ${ }^{128}$ The level of Lake Ngami (Botswana) was also high in the 1780s, consistent with other historical information. However, there are several references to protracted drought in the western Cape Province (South Africa) in 1783-85. The drought broke in 1786, allowing for a good harvest in 1787 and the following few years. Drought occurred in the central Cape Province in 1789 and 1790 and in the eastern Cape Province in 1783 and 1784..$^{129}$

From this miscellaneous information two patterns seem to emerge. In the eastern half of Africa, it appears that rainfall in the 1780s was relatively good in the winter rains region north of the Sahara along the Mediterranean coast and in the northern and southern subtropical latitudes, including the eastern Sahel. However, the eastern equatorial regions experienced a preponderance of drought. This pattern is a common one. ${ }^{130}$ In the western half of Africa, the opposite appears to have occurred: relatively wet conditions in the equatorial latitudes of the Guinea coast, but drought in Angola, the western Sahel, and extra-tropical regions further north. While that is also a common pattern, the east-west contrast overall is not. This suggests unusual forcing of conditions in the 1780s.

\section{Conclusions}

Climate events of the 1780s and early 1790s produced very unsettled conditions around the world. These events included very strong La Niña and El Niño events and a major volcanic eruption in Iceland-although R. D'Arrigo and colleagues have suggested that conditions may have actually resulted from the occurrence of a negative NAO phase coupled with a protracted El Niño in 1782-1784. In contrast to Grove, Gergis and Fowler have concluded that a very strong La Niña event (not El Niño) was centred on 1788 and spanned to 1790. A characteristic "phase flip" seems to have occurred in 1791, bringing a strong El Niño event that lasted until $1793 .{ }^{131}$ It is important to note that extreme phases of the ENSO cycle frequently result in extreme weather conditions around a large part of the globe. ${ }^{132}$ In the western Pacific, El Niño events increase the likelihood of severe drought, while La Niña conditions favour the above average rainfall and flooding. ${ }^{133}$ Typically, the

\footnotetext{
127 Tyson, 1986.

128 Nicholson, 1981.

129 Theal, 1888.

130 Nicholson, 2014.

131 Gergis and Fowler, 2009.

132 Diaz and Markgraf, 2000.

133 Allan et al. 1996; Risbey et al. 2009.
} 
reverse is true in the Eastern Pacific with heavy rainfall experienced during El Niño episodes. ${ }^{134}$ These patterns can be observed in the case studies that we have examined.

The case studies also reveal societal vulnerability to the cycle of floods and droughts, in terms of the loss of livelihoods, disease, and death for the populations involved. While some of the famines, for example in India, were exacerbated by factors such as colonial taxation policies and East India Company intransigence, most of the 1780s famines were at least in part-although as described above, through notably complex causal links-born of climatic irregularities. In India, the climatic element of the famine was lack of rain from 1789 onwards, although disruption to the expected timing of rains, some excessive rains, and a season of very extreme storms, floods, and intense winds in 1787 also contributed. While statistical data is absent, qualitative assessment of the 179092 famines suggests they were the most severe of the period, in line with the climate anomalies recorded by climatologists. In Australia, La Niña conditions and flooding in 1788 were followed by a prolonged period of drought until 1792, causing very unsettled conditions for the emerging colony. In Japan, the great "Tenmei" Famine, which caused some hundred thousand deaths, followed extremely poor rice harvests brought by cold summer weather in northern to eastern Japan during the 1780s, particularly 1783-84 and 1786. In Egypt, the impact of the Laki eruption was immense, and drought and hunger in 1784-85 left people vulnerable to plague and other diseases. Elsewhere in Africa, it appears that years of the 1780s brought lower rainfall and even droughts in the eastern equatorial regions, and wet conditions in equatorial latitudes of the Guinea coast but drought in the western Sahel, and Angola. East-West contrast showed unusual forcing of conditions in the 1780s. These case studies highlight the unsettled conditions of the period and the cycle of ENSO that defines so much of living conditions in many parts of the world today.

It is clear that a better understanding of the ENSO cycles and its links with the Asian monsoon is critical to understanding the history of "floods, famines, and empires" in different parts of the world. ${ }^{135}$ The documentary and non-instrumental historical record gathered from the natural history collections of European empires are vital to this ongoing interdisciplinary project on the historical study of climate and society.

\section{References}

Adamson, George C. D., and David J. Nash. "Long-Term Variability in the Date of Monsoon Onset over Western India." Climate Dynamics 40 (2013): 2589-2603.

Akinjogbin, I. A. Dahomey and Its Neighbours: 1708-1818. Cambridge University Press, 1967.

\footnotetext{
134 Allan et al., 1996.
}

135 Fagan, 2009. 
al-Jabartī, Abd al-Raḥman. Abd Al-Raḥman Al-Jabartī's History of Egypt: "Ajā"ib Al-Āthār Fī Al-Tarājim Wa Al-Akhbār. Edited by Thomas Philipp and Moshe Perlmann. 4 vols. Stuttgart: Franz Steiner Verlag, 1994.

al-Khashshāb, Ismā'îl ibn Sa'd. Khulāșat Mã Yurād Min Akhbār Al-Amīr Murād. Translated by Daniel Crecelius and Ḥamza 'Abd al-'Aziz Badr. Cairo: al-'Arabī lil-Nashr wa al-Tawzī', 1992.

Alcoforado, M. J. et al. "Early Portuguese Meteorological Measurements (18th Century)." Climate of the Past 8 (2012): 353-71.

Allan, Robert J., and Rosanne D. D'Arrigo. "Persistent' ENSO Sequences: How Unusual Was the 1990-1995 El Niño?" The Holocene 9 (1999): 101-18.

Almeida, Raymond A. "Chronological References: Cabo Vere/Cape Verdean American," 1997.http://www1.umassd.edu/specialprograms/caboverde/cvchrono.html.

Ananthasubramaniam, C. K. "The Madras Observatory, 1792-1931." Journal of the Royal Astronomical Society of Canada 85 (1991): 97-106.

Becker, Charles. "Notes Sur Les Conditions Ecologiques En Senegambie Aux 17e et 18e Siecles." African Economic History 14 (1985): 167-216.

Bell, Barbara. "The Oldest Records of the Nile Floods." The Geographical Journal 136 (1970): 569-73.

Bjarnar, Vilhjálmur T. The Laki Eruption and the Famine of the Mist. Published for the American-Scandinavian Foundation by the University of Washington Press, 1965.

Bois, Charles. Années de disette, années d'abondance: Sécheresses et pluies en Tunisie de 648 à 1881. Tunis, 1944.

Brohan, P. et al. "Constraining the Temperature History of the Past Millennium Using Early Instrumental Observations." Climate of the Past 8 (2012): 1551-63.

Brooks, George E. "Cabo Verde: Gulag of the South Atlantic: Racism, Fishing Prohibitions, and Famines." History in Africa 33 (2006): 101-35.

Browne, William George. Travels in Africa: Egypt, and Syria from the Year 1792 to 1798. London: T. Cadell Junior and W. Davies, 1799.

Buckley, Brendan M. et al. "Monsoon Extremes and Society over the Past Millennium on Mainland Southeast Asia." Quaternary Science Reviews 95 (2014): 1-19.

Camberlin, Pierre. "Rainfall Anomalies in the Source Region of the Nile and Their Connection with the Indian Summer Monsoon." Journal of Climate 10 (1997): 1380.

Campbell, George, and William Wilson Hunter. Extracts from Records in the India Office Relating to Famines in India 1769-1788. Calcutta: Office of Superintendent of Government Printing, 1868.

Chenoweth, Michael, and Thomas Thistlewood. The 18th Century Climate of Jamaica, Derived from the Journals of Thomas Thistlewood, 1750-1786. Philadelphia: American Philosophical Society, 2003.

Cook, Edward et al. "Asian Monsoon Failure and Megadrought During the Last Millennium." Science 328 (2010): 486-89. 
Cotte, L., Thierry de Villedavray, and Bern Dibner. Mémoires sur la météorologie, pour servir de suite et de supplément au traité de meteorology, publié en 1774. Paris: De l'Imprimerie Royale, 1788.

Dalzel, Archibald. The History of Dahomey, an Inland Kingdom of Africa: Compiled from Authentic Memoirs. London: The Author, 1793.

Damodaran, Vinita. "The East India Company, Famines and Ecological Conditions in Eighteenth Century Bengal." In The East India Company and the Natural World, edited by Anna Winterbottom, Alan Lester, and Vinita Damodaran, 2015.

D'Arrigo, Rosanne et al. “The Anomalous Winter of 1783-1784: Was the Laki Eruption or an Analog of the 2009-2010 Winter to Blame?" Geophysical Research Letters 38 (2011): L05706.

Danvers, F.C. A Century of Famines. Calcutta, India, 1877.

Debien, Annekatrien, et al. "Influence of Satellite-Derived Rainfall Patterns on Plague Occurrence in Northeast Tanzania." International Journal of Health Geogaphics 9 (2010): 60 .

Demarée, G. R., and A. E. J. Ogilvie. “Bon Baisers d'Islande: Climatological, Environmental and Human Dimensions Impacts in Europe of the Lakagígar Eruption (1783-1784) in Iceland." In History and Climate: Memories of the Future?, 219-46. New York; Boston: Kluwer Academic/Plenum Publishers, 2001.

Demarée, G.R., and A. E. J. Ogilvie. "Comment on Stothers, R.B. The Great Dry Fog of 1783 (Climatic Change 32, 1996): Further Documentary Evidence of Northern Hemispheric Coverage of the Great Dry Fog of 1783." Climatic Change 39 (1998): 727-30.

Elliot, Walter. "On the Farinaceous Grains and the Various Kinds of Pulse Used in Southern India." Transactions of the Botanical Society of Edinburgh 7 (1863): 275-300.

Endfield, Georgina H. Climate and Society in Colonial Mexico: A Study in Vulnerability. Malden, MA: Blackwell Publishers, 2008.

Fagan, Brian M. Floods, Famines, and Emperors: El Niño and the Fate of Civilizations. 2nd ed. New York: Basic Books, 2009.

Franklin, Benjamin. "Meteorological Imaginations and Conjectures." Memoirs of the Manchester Literary and Philosophical Society, 1785, 373-77.

Gergis, J., D.J. Karoly, and R.J. Allan. "A Climate Reconstruction of Sydney Cove, New South Wales, Using Weather Journal and Documentary Data, 1788-1791." Australian Meteorological Magazine58 (2009): 83-98.

Gergis, Joëlle, Philip Brohan, and Rob Allan. "The Weather of the First Fleet Voyage to Botany Bay, 1787-1788.” Weather 65 (2010): 315-19.

Gergis, Joëlle, and Anthony Fowler. "A History of El Niño-Southern Oscillation (ENSO) Events Since A.D. 1525: Implications for Future Climate Change." Climatic Change 92 (2009): 343-87.

Gettelman, A., A. Schmidt, and J. E. Kristjánsson. "Icelandic Volcanic Emissions and Climate." Nature Geoscience 8 (2015): 243. 
Grattan, John, et al. "Volcanic Air Pollution and Mortality in France 1783-1784." Comptes Rendus - Géoscience 337 (2005): 641-51.

Grove, Richard. "Global Impact of the 1789-93 El Niño." Nature 393 (1998): 318-19.

- _ . "The Great El Niño of 1789-93 and Its Global Consequences: Reconstructing an Extreme Climate Event in World Environmental History." The Medieval History Journal 10 (2007): 75-98.

Gunnlaugsson, G. A. et al. eds. Skaftáreldar 1783-1784: Ritgerð̌r og Heimildir. Reykjavík: Mál og Menning, 1984.

Hunter, J. An Historical Journal of the Transactions at Port Jackson and Norfolk Island: Including the Journals of Governors Phillip and King, since the Publication of Phillip's Voyage: With an Abridged Account of the New Discoveries in the South Seas. London: John Stockdale, Piccadilly, 1793.

Hunter, William Wilson, James Sutherland Cotton, Richard Burn, and William Meyer. Imperial Gazetteer of India. Oxford: Clarendon Press, 1907-1909.

Kington, J. A. "The Warmest Month in the Central England Temperature Series." Climate Monitor3 (1783): 69-73.

Kington, J.A. The Weather of the 1780s over Europe. Cambridge: Cambridge University Press, 2009.

Lehman, John T., ed. "Historical Fluctuations of Lake Victoria and Other Lakes in the Northern Rift Valley of East Africa." In Environmental Change and Response in East African Lakes, 7-36. Dordrecht; Boston: Kluwer Academic Publishers, 1998.

Lyons, H. G. "On the Nile Flood and Its Variation.” The Geographical Journal26 (1905): 24972.

Marchika, Jean. "La peste en Afrique septentrionale: Histoire de la peste en Algérie de 1363 à 1830." University of Algiers, 1927.

Matthews, John. A Voyage to the River Sierra-Leone, on the Coast of Africa. London: Printed for B. White and Son, and J. Sewell, 1788.

Mauritius Meteorological Service. Meteorology in Mauritius, 1774-1974. Port Louis: The Mauritius Printing Co. Ltd, 1974.

Mercer, Patricia. "Drought and Famine in Two Areas of Northwestern Africa during the 17th and 18th Centuries." African History Seminar, School of Oriental and African Studies, University of London, 1974.

Mikami, Takehiko. "Classification of Natural Seasons in Japan for Summer Half Years 178190 Based on the Seasonal March of Weather." Journal of Geography (Tokyo Geographical Society) 92 (1983): 105-15.

- - - "Climate of Japan during 1781-90 in Comparison with that of China." In The Climate of China and Global Climate, edited by D. Ye, C. Fu, J. Chao, and Yoshino, 63-75. Beijing, China: China Ocean Press, 1987.

- - C. "Climatic Variations in Japan Reconstructed from Historical Documents." Weather 63 (2008): 190-93. 
- - - "Long Term Variations of Summer Temperatures in Tokyo since 1721." Geographical Report of Tokyo Metropolitan University 31 (1996): 157-66. Mikhail, Alan. Nature and Empire in Ottoman Egypt: An Environmental History. Cambridge, U.K.; New York: Cambridge University Press, 2013.

- - . "Ottoman Iceland: A Climate History." Environmental History 20 (2015): 262-84.

- - . "The Nature of Plague in Late Eighteenth-Century Egypt." Bulletin of the History of Medicine 82 (2008): 249-75.

Miles, Richard. "Copy of Letter from Richard Miles Esq. Governor of Cape Coast Castle Dated 2nd, 12th and 22nd June," 1782. The National Archives London.

Miller, Joseph C. "The Significance of Drought, Disease and Famine in the Agriculturally Marginal Zones of West-Central Africa." The Journal of African History23 (1982): 1761.

Morgue, J. "Copy of a Letter from the Council at Cape Coast Castle Dated March 31," 1784. The National Archives London.

Nash, David J., and George C. D. Adamson. "Recent Advances in the Historical Climatology of the Tropics and Subtropics." Bulletin of the American Meteorological Society 95 (2014): 131-46.

Nicholson, S. E. "The Nature of Rainfall Variability over Africa on Time Scales of Decades to Millennia." Global and Planetary Change 26 (2000): 137-58.

Nicholson, Sharon. "Historical Fluctuations of Lake Victoria and Other Lakes in the Northern Rift Valley of East Africa." In Environmental Change and Response in East African Lakes, edited by J.T. Lehman, 7-36. Dordrecht: Kluwer Academic Publishers, 1998.

Nicholson, Sharon E. "Fluctuations of Rift Valley Lakes Malawi and Chilwa during Historical Times: A Synthesis of Geological, Archaeological and Historical Information." In Environmental Change and Response in East African Lakes, edited by John T. Lehman, 207-32. Dordrecht; Boston: Kluwer Academic Publishers, 1998.

- - - "Saharan Climates in Historic Times." In The Sahara and the Nile: Quaternary Environments and Prehistoric Occupation in Northern Africa, edited by M. A. J. Williams and H. Faure, 173-200. Rotterdam: Balkema, 1980.

- - . "Spatial Teleconnections in African Rainfall: A Comparison of 19th and 20th Century Patterns." The Holocene24 (2014): 1840-48.

- - . "The Historical Climatology of Africa." In Climate and History: Studies in Past Climates and Their Impact on Man, edited by T. M. L. Wigley, M.J. Ingram, and G. Farmer, 249-70. Cambridge: Cambridge University Press, 1981.

Norrgård, Stefan. A New Climatic Periodisation of the Gold and Guinea Coasts in West Africa, 1750-1798: A Reconstruction of the Climate during the Slave Trade Era, Including an Analysis of the Climatically Facilitated Trans-Atlantic Slave Trade. Åbo: Åbo Akademi University Press, 2013. 
- - - "Practising Historical Climatology in West Africa: A Climatic Periodisation 17501800." Climatic Change129 (2015): 131-43.

Ogilvie, A. E. J. "Historical Climatology, Climatic Change, and Implications for Climate Science in the Twenty-First Century." Climatic Change 100 (2010): 33-47.

- - . "The Climate of Iceland, 1701-1784."Jökull 36 (1986): 57-73.

Ogot, Bethwell A. Africa from the Sixteenth to the Eighteenth Century. London; Berkeley; Paris: Heinemann; University of California Press; UNESCO, 1992.

Oman, L. et al. "High-Latitude Eruptions Cast Shadow over the African Monsoon and the Flow of the Nile." Geophysical Research Letters 33 (2006).

Oman, Luke et al. "Climatic Response to High-Latitude Volcanic Eruptions." Journal of Geophysical Research: Atmospheres 110 (2005): 1.

Ortlieb, L. "The Documented Historical Record of El Niño Events in Peru: An Update of the Quinn Record (Sixteenth through Nineteenth Centuries)." In El Niño and the Southern Oscillation: Multiscale Variability and Global and Regional Impacts, edited by Henry F. Diaz and Vera Markgraf, 207-95. Cambridge; New York: Cambridge University Press, 2000.

Patnaik, Dipankar Chyau, and N. Sivagnanam. "Cyclonic Storms and Odisha Coast." SSRN Scholarly Paper. Rochester, NY: Social Science Research Network, 2007.

Patterson, K. D. "Epidemics, Famines, and Population in the Cape Verde Islands, 15801900." The International Journal of African Historical Studies21 (1988): 291-313.

Purdy, John. The Oriental Navigator, Or, Directions for Sailing To, From, and upon the Coasts Of, the East-Indies, China, Australia... London: Printed for James Whittle and Richard Holmes Laurie, 1816.

Revel, Marie, E. et al. "100,000 Years of African Monsoon Variability Recorded in Sediments of the Nile Margin." Quaternary Science Reviews 29 (2010): 1342-62.

Ridley, D. A. et al. "Total Volcanic Stratospheric Aerosol Optical Depths and Implications for Global Climate Change." Geophysical Research Letters 41 (2014): 7763-69.

Robock, Alan. "Volcanic Eruptions and Climate." Reviews of Geophysics 38 (2000): 191-219. Roxburgh, William. Flora Indica; Or, Descriptions of Indian Plants, Volume 2. New York: Oriole Editions, 1975.

Santer, B. D. et al. "Human and Natural Influences on the Changing Thermal Structure of the Atmosphere." Proceedings of the National Academy of Sciences of the United States of America 110 (2013): 17235-40.

Santer, Benjamin D. et al. "Observed Multivariable Signals of Late 20th and Early 21st Century Volcanic Activity." Geophysical Research Letters 42 (2015): 500-509.

Shanahan, T. M. et al. "Atlantic Forcing of Persistent Drought in West Africa."Science 324 (2009): 377-80.

Shaw, Stanford J. The Financial and Administrative Organization and Development of Ottoman Egypt, 1517-1798. Princeton: Princeton University Press, 1962. 
Shi, F., J. Li, and R. J. Wilson. "A Tree-Ring Reconstruction of the South Asian Summer Monsoon Index over the Past Millennium." Scientific Reports 4 (2014): 6739.

Stothers, Richard B. "The Great Dry Fog of 1783."Climatic Change 32 (1996): 79-89.

Theal, George McCall. History of South Africa, 1691-1795. London: S. Sonnenschein \& Co., 1888.

Thordarson, Th., and S. Self. "The Laki (Skaftár Fires) and Grímsvötn Eruptions in 17831785." Bulletin Volcanologique 55 (1993): 233-63.

Thordarson, Thorvaldur, and Stephen Self. "Atmospheric and Environmental Effects of the 1783-1784 Laki Eruption: A Review and Reassessment." Journal of Geophysical Research: Atmospheres 108 (2003): AAC 7-1 - AAC 7-29.

Thórarinsson, S. "On the Damage Caused by Volcanic Eruptions with Special Reference to Tephra and Gases." In Volcanic Activity and Human Ecology, edited by Payson D. Sheets and Donald K. Grayson. New York: Academic Press, 1979.

_- - "The Lakagígar Eruption of 1783."Bulletin Volcanologique33 (1969): 910-29.

Trail, H. "A Meteorological Diary, Kept at Calcutta from the 1st February 1784 to 31st October 1785." Asiatic Researches2 (1799): 419-70.

Tyson, Peter D. Climatic Change and Variability in Southern Africa. Cape Town: Oxford University Press, 1986.

Verschuren, D., K. R. Laird, and B. F. Cumming. "Rainfall and Drought in Equatorial East Africa During the Past 1,100 Years." Nature 403 (2000): 410-14.

Volney, Constantin-François. Travels through Egypt and Syria, in the Years 1783, 1784, and 1785. Containing the Present Natural and Political State of Those Countries, Their Productions, Arts, Manufactures, and Commerce; with Observations on the Manners, Customs, and Government of the Turks and Arabs. New York: Printed by J. Tiebout, for E. Duyckinck \& Co. Booksellers., 1798.

Watts, Martin. "Copy of Letter from Martin Watts at Fort Apollonia Dated March 10," 1784. The National Archives London.

"Corringa Storm." The Nautical Magazine, 1832.

Webster, J. B. "Noi! Noi! Famines as an Aid to Interlacustrine Chronology." InChronology, Migration, and Drought in Interlacustrine Africa, 1-37. New York: Africana Publishing Company, 1978.

Zaiki, M., M. Grossman, and T. Mikami. "Document-Based Reconstruction of Past Climate in Japan." PAGES News 20 (2012): 82-83.

Zuidervaart, H. J., and Robert H. van Gent.Between Rhetoric and Reality: Instrumental Practices at the Astronomical Observatory of the Amsterdam Society "Felix Meritus" 1768-1889. Hilversum: Verloren, 2013.

Zuidervaart, H. J., and R. H. van Gent. "'A Bare Outpost of Learned European Culture on the Edge of the Jungles of Java': Johan Maurits Mohr (1716-1775) and the Emergence of Instrumental and Institutional Science in Dutch Colonial Indonesia." Isis 95 (2004): 133. 